\title{
Sędziowski obowiązek wydania wyroku: regulacje prawa rzymskiego na tle prawa polskiego
}

I. Wielekroć przychodzi sędziom stanąć przed znacznymi trudnościami w wykonaniu ciążącego na nich obowiązku wymierzenia sprawiedliwości. Oczywiście nie chodzi o problemy wynikające z prostego braku przygotowania do rozpoznania sprawy pod względem faktycznym czy prawnym, ale o prawdziwe dylematy etyczne, a czasem etyczno-prawne. Tytułem przykładu warto przytoczyć jedną z historii podawanych przez starożytnych autorów, doskonale ilustrującą przypadki trudne, jeśli nawet nie niemożliwe do jednoznacznego rozstrzygnięcia. W dziele Noctes Atticae Aulusa Gelliusa ${ }^{1}$, uczonego i pisarza rzymskiego z drugiej połowy II wieku, przytoczona została historia zaczerpnięta z niezachowanej do naszych czasów pracy Studiosorum Pliniusa Secundusa (Pliniusza Starszego), odnosząca się do argumentacji przytaczanej $\mathrm{w}$ toku procesu o ... żonę. Podstawę prawną sporu stanowiło prawo pozwalające dzielnym mężom na otrzymanie nagrody za mężne czyny. Otóż, pewien mężczyzna, korzystając z tejże regulacji, po dokonaniu bohaterskiego czynu zażądał, by w nagrodę została mu dana za żonę kobieta, będąca żoną innego mężczyzny. I taką nagrodę, zgodnie z prawem, otrzymał. Wówczas ten, który żony został pozbawiony, dokonał czynu jeszcze bardziej heroicznego, po czym zażądał jako nagrody - zwrotu zabranej mu kobiety. Mężczyźni nie mogli dojść do porozumienia i sprawa oparła się o sąd. Tam powód (mężczyzna, który pierwszy żonę utracił) argumentował za swoją wygraną w ten sposób: ,jeśli ustawa obowiązuje, oddasz mi żonę, a jeśli nie obowiązuje, też mi ją oddasz"2.

${ }^{1}$ Aulus Gellius był rzymskim kolekcjonerem ciekawostek, które zebrał i omówił, z przeznaczeniem dla własnych dzieci, w pracy Noctes Atticae. Należał do stanu ekwitów, pełnił funkcje urzędnicze, sprawował czynności sędziego. Znany jest jedynie dzięki swojej pracy, która stanowi źródło bogatych informacji na temat literatury, języka, kultury, prawa i innych aspektów życia codziennego starożytnych Greków i Rzymian. Szerzej na temat Aulusa Gelliusa zob. zwłaszcza J. Zabłocki, Rozważania o procesie rzymskim w Noctes Atticae Aulusa Gelliusa, Warszawa 1999, s. 7-49 wraz z powołaną bogatą literaturą.

${ }^{2}$ Gellius, Noctes Atticae 9,16,5-6: Sicuti hanc quoque sententiam ponit ex huiuscemodi controversia: ,, Vir fortis praemio, quod optaverit, donetur. Qui fortiter fecerat, petit alterius uxorem in 
W pierwszym przypadku bowiem - jak dowodził - winien dostać żonę $\mathrm{z}$ powrotem $\mathrm{w}$ charakterze nagrody przepisanej prawem, $\mathrm{w}$ drugim zaś z uwagi na bezprawność zaboru. Zasadniczy problem w rozstrzygnięciu wynikał jednak z faktu, iż pozwany mógł przeciwstawić się niemal tożsamym dictum: ,jeśli ustawa obowiązuje, nie oddam ci żony, a jeśli nie obowiązuje, też ci jej nie oddam". Pozwany wskazywał bowiem, że w pierwszym przypadku otrzymał ją jako należną nagrodę, a w drugim - że nagroda nie należy się powodowi ${ }^{3}$.

II. Rzymskie rem sibi non liquere. Oczywiście nie tylko zaistnienie tak skomplikowanych stanów faktycznych mogło powodować trudności orzecznicze. W realiach starożytnego Rzymu nie można bowiem pomijać okoliczności, iż - w procesie legisakcyjnym i formułkowym - sędzią była osoba prywatna, powoływana przez magistrature jurysdykcyjną do rozstrzygnięcia konkretnej sprawy. Aby wybrać sędziego, zwykle posługiwano się przygotowaną przez pretora, a w okresie pryncypatu przez cesarza, listą osób spełniających wymagania stawiane sędziom (album iudiciorum selectorum) ${ }^{4}$. Na liście tej mógł znaleźć się każdy obywatel rzymski płci męskiej zajmujący odpowiednio wysoką pozycję społeczną: początkowo byli to wyłącznie senatorowie, później także ekwici (najpewniej od lex Sempronia iudiciaria z 122 r. p.n.e.), a przejściowo nadto tribuni aerarii (od lex Aurelia iudiciaria z 70 r. p.n.e. do lex Iulia iudiciaria z 46 r. p.n.e. $)^{5}$. Przypuszcza się, że początkowo niezbędne było spełnienie wymogu ukończenia 35 lat, zaś od Augusta 30 lat $^{6}$. Co istotne, w Rzymie okresu klasycznego nie wymagano od sędziów wiedzy i praktyki

matrimonium et accepit. Is deinde, cuia uxor fuit, fortiter fecit. Repetit eandem; contradicitur". Eleganter inquit et probabiliter ex parte posterioris viri fortis uxorem sibi reddi postulantis hoc dictum est: "Si placet lex, redde; si non placet, redde”.

${ }^{3}$ Szerzej na ten temat zob. J. Zabłocki, Rozważania..., s. 98-100. W dziele Aulusa Gelliusa podana jest podobna historia - procesu greckiego sofisty Protagorasa, wytoczonego przeciwko uczniowi Euathlosowi o zapłatę wynagrodzenia (Gellius, Noctes Atticae 5,10,4-14). Euathlos pobierał lekcje wymowy u Protagorasa, przy czym połowę wynagrodzenia za naukę uiścił na początku zajęć, a drugą część zobowiązał się zapłacić dopiero po wygraniu pierwszego procesu sądowego. Kiedy sofista nie mógł doczekać się zapłaty, wytoczył proces, w którym argumentował, że młodzieniec będzie zmuszony zapłacić: albo na mocy wyroku zasądzającego, a gdyby taki nie zapadł - na mocy umowy. Wówczas Euathlos miał odpowiedzieć, że rzecz ma się wręcz przeciwnie: nie będzie zmuszony do zapłaty, ponieważ albo sprawa zostanie rozstrzygnięta na jego korzyść i wyrok zwolni go od obowiązku zapłaty, albo na korzyść Protagorasa i wtedy - zgodnie z umową - nie będzie należała mu się zapłata. W istocie należy wskazać, że stanowiska obu oponentów są sprzeczne nie tylko między sobą, ale także wewnętrznie: każdy z nich zakłada bowiem, że będzie akceptować wyrok, jeżeli będzie dla niego korzystny, a jeśli byłby on niekorzystny - wówczas przyjdzie odwołać się do umowy.

${ }^{4}$ Cicero, Pro Cluentio 43,121; Suetonius, Divus Augustus 32.

${ }^{5}$ Szerzej zob. np. J. Zabłocki, Iudex qui iuravit sibi non liquere, „Prawo Kanoniczne” 39(1996), nr 3-4, s. 215 wraz z powołaną literatura.

${ }^{6}$ Szerzej na temat sporów w literaturze na ten temat zob. J. Zabłocki, Iudex..., s. 215; idem, Rozważania.., s. 83-84. 
prawniczej, a to z pewnością nie sprzyjało sprawności i łatwości rozstrzygania problemów faktycznych i prawnych.

W rzymskim procesie (legisakcyjnym i formułkowym) występowało wyraźne odróżnienie dwóch faz: pierwszej toczącej się przed urzędnikiem, zwykle pretorem (in iure), oraz drugiej odbywającej się przed sędzią prywatnym lub sędziami wybranymi przez strony lub wskazanymi przez urzędnika z oficjalnej listy (apud iudicem). System ten obowiązywał do czasów wyparcia procesu zwyczajnego przez cognitio extra ordinem, w którym całe postępowanie prowadzone było przed urzędnikiem sądowym. W przypadku procesu dwufazowego, pierwsza faza poświęcona była na sprecyzowanie żądania i zakresu orzekania przez sędziego, druga zaś - przeprowadzeniu postępowania dowodowego i wydaniu wyroku. Jest niezwykle charakterystyczne, że Instytucje Gajusa określają szczegółowo pierwszy etap postępowania, niewiele uwagi poświęcając drugiemu, a zwłaszcza obowiązkom sędziego (officium iudicis). Wiadomo jedynie, że prawnik Q. Elius Tuberus napisał dzieło De officio iudicis, ale niestety nie zachowało się ono do naszych czasów ${ }^{7}$.

Jeżeli chodzi o wagę obowiązków sędziego, należy wskazać, że już ustawa XII tablic przewidywała karę śmierci dla sędziego, który orzekł zgodnie z żądaniem tego, od kogo otrzymał pieniądze ${ }^{8}$. Nie później niż w II wieku p.n.e. przyjęta została odpowiedzialność sędziego, który spór uczynił własnym (litem suam facere) przez niewłaściwe postępowanie: niewydanie wyroku, niedotrzymanie terminów rozpraw, nieobecność w czasie rozprawy, niezgodność wyroku z formułą procesową wskazaną w condemnatio itp. ${ }^{9}$ Ważne było zatem, by wydane przez sędziego orzeczenie było zgodne z prawem oraz jego sumieniem. $\mathrm{Z}$ zainteresowaniem zatem przychodzi pochylić się nad sytuacjami, w których sędzia prywatny stawał przed trudnościami, których z powodu braku wiedzy prawniczej i umiejętności orzeczniczych sam pokonać nie potrafił.

Ulpianus, D. 5,1,79,1: Iudicibus de iure dubitantibus praesides respondere solent: de facto consulentibus non debent praesides consilium impertire, verum iubere eos prout religio suggerit sententiam proferre: haec enim res nonnumquam infamat et materiam gratiae vel ambitionis tribuit.

${ }^{7}$ A.M. Rabello, Non Liquet: From Modern Law to Roman Law, „Annual Survey of International \& Compartive Law" 10(2004), s. 14.

${ }^{8}$ Gellius, Noctes Atticae 20,1,7: nisi duram esse legem putas, quae iudicem arbitrumve iure datum, qui ob rem dicendam pecuniam accepisse convictus est, capite poenitur... Szeroko na temat odpowiedzialności sędziego zob. np. G. MacCormack, The Liability of the Judge in the Republic and Principate, ANRW 2.14, s. 3-28; M. i J. Zabłoccy, Ustawa XII tablic. Tekst, tlumaczenie, objaśnienia, Warszawa 2000, s. 64, 65; J. Zabłocki, Rozważania ..., s. 54; T. Palmirski, Obligationes quasi ex delicto. Ze studiów nad źródłami zobowiazań w prawie rzymskim, Kraków 2004, s. 27-39.

${ }^{9}$ Szerzej na ten temat zob. np. A. d'Ors, Litem suam facere, SDHI 48(1982), s. 368-394; O.F. Robinson, The iudex qui litem suam fecerit explained, ZSS RA 116(1999), s. 195-199; T. Palmirski, op. cit., s. 40-67 wraz z powołaną tam literaturą. 
W przekazanym w Digestach fragmencie wypowiedzi Ulpiana wskazano, że w przypadku zgłaszania przez sędziego wątpliwości natury prawnej, namiestnik prowincji może je rozwiać. Natomiast w razie wątpliwości co do stanu faktycznego, namiestnik winien powstrzymać się od udzielenia rad sędziemu, ograniczając się do wskazówki wydania wyroku zgodnie z wewnętrznym przekonaniem orzekającego. Ingerencja namiestnika w tym ostatnim przypadku mogłaby bowiem być wyjątkowo szkodliwa dla wymiaru sprawiedliwości. Stanowisko takie oznaczało obowiązek udzielania pomocy jedynie co do wątpliwości prawnych i nakaz powstrzymywania się od rozstrzygania za sędziego wątpliwości faktycznych, a zatem od oceny materiału dowodowego ${ }^{10}$.

W tym miejscu warto przytoczyć najbardziej znany w literaturze przypadek dylematów sędziego, który czuł się niezdolny do wydania orzeczenia. Wspomniany już wcześniej Aulus Gellius, mimo braku przygotowania prawniczego oraz braku praktyki prawnej, został powołany do pełnienia obowiązków sędziego prywatnego - miał rozstrzygnąc sprawę o zwrot pożyczki pieniężnej ${ }^{11}$. W toku postępowania powód nie dostarczył jednak dokumentów potwierdzających zawarcie umowy pożyczki, nie przedstawił świadków na tę okoliczność, nie skorzystał nawet z mniej wiarygodnych środków dowodowych. Gellius jako sędzia nie mógł jednak pominąć tego, że powód był osobą o nieposzlakowanej opinii, godną zaufania, cieszącą się szacunkiem z uwagi na powszechnie znaną dobroć. Tymczasem pozwany, choć korzystnie ustosunkowany, znany był z postaw wiarołomnych.

Pozwany w toku procesu domagał się przedstawienia dowodów na zawarcie umowy, a gdyby to nie nastapiło, żądał, aby w drodze iudicium calumniae decima partis obciążyć powoda z powodu bezpodstawnego prowadzenia procesu. Damnatus de calumnia płacił zaś dziesiątą część tego, czego domagał się niezasadnie $\mathrm{w}$ procesie ${ }^{12}$.

Gellius, przekonany o dobrej reputacji powoda i złej reputacji pozwanego, nie chciał wydać orzeczenia pochopnie, stąd zwrócił się o udzielenie pomocy do przyjaciół. Ci nie byli zbyt przekonywający dla Gelliusa, zwłaszcza że nie mieli zbyt wiele czasu, by poświęcić się głębszej analizie sporu; przyjaciele jednak zgodnie sugerowali uwolnienie pozwanego, skoro powód nie udowodnił, że do zawarcia umowy pożyczki doszło ${ }^{13}$. Niejako na marginesie rozważań można wskazać, że rada przyjaciół Gelliusa była jak najbardziej prawidłowa: zadaniem sędziego prywatnego było bowiem rozstrzygnięcie czy stan faktycz-

${ }^{10}$ Warto ten tekst przytoczyć w kontekście podjętych rozważań, choć był on wielokrotnie atakowany oskarżeniami o interpolacje. Zarzuty w tym zakresie omawia A.M. Rabello, op. cit., s. 15, przyp. 50, wskazując jednak, że zarzuty te mają charakter formalnych, sama zaś myśl może zostać przypisana prawnikowi klasycznemu.

${ }^{11}$ Gellius, Noctes Atticae 14,2,4.

${ }^{12}$ G. 4,174-179.

${ }^{13}$ Gellius, Noctes Atticae 14,2,9-10. 
ny opisany w formułce procesowej ułożonej przez pretora zaistniał - jeśli tak, należało pozwanego zasądzić, jeśli nie - należało pozwanego uwolnić. Skoro zatem w rozważanym przez Gelliusa przypadku powód nie wykazał, by stan faktyczny opisany w formułce odpowiadał rzeczywistości, obowiązkiem sędziego było oddalenie powództwa ${ }^{14}$.

Powracając jednak do przypadku Gelliusa, należy wskazać, że nie postąpił on zgodnie z radami przyjaciół, a zatem nie wydał wyroku uwalniającego pozwanego, lecz zawiesił na pewien czas rozpoznanie sprawy i zwrócił się o pomoc do jednego ze znanych filozofów, Favorinusa. Ten, odnosząc się do obowiązków sędziego, postawił pytanie, czy obowiązkiem sędziego jest opierać się wyłącznie na danych przedstawionych w toku procesu, czy też może lub powinien on wykorzystywać także wiedzę o sprawie i jej stronach uzyskaną wcześniej z innych źródeł ${ }^{15}$. Filozof przywołał pogląd Katona, wyrażony w obronie Luciusa Turiusa przeciwko Gneiusowi Gelliusowi, wedle którego, jeżeli sporna sprawa nie mogła być rozstrzygnięta na podstawie dowodów z dokumentów czy zeznań świadków, sędzia winien ustalić, jaką sławą cieszą się oponenci sporu, a dopiero kiedy obaj byli równie szlachetni lub równie niegodziwi, winien sprawę osądzić na korzyść pozwanego ${ }^{16}$. W konsekwencji Favorinus, powołując się na cytowaną opinię Katona, radził dać wiarę powodowi a nie pozwanemu ${ }^{17}$, zgodnie $\mathrm{z}$ zasadą qui petit melior est.

W rezultacie Gellius otrzymał sprzeczne rady - od przyjaciół, „by uwolnił pozwanego”, zaś od filozofa, „by zasądził pozwanego”. Żadne ze stanowisk go jednak w pełni nie przekonało, więc uchylił się od wydania wyroku. Powołał się na swój młody wiek oraz brak doświadczenia i złożył przysięgę sibi non liquere ${ }^{18}$.

Powracając do głównego nurtu rozważań, należy przypomnieć, że prawo rzymskie nakładało na sędziego obowiązek wydania wyroku, przy czym w przypadku naruszenia tego obowiązku sędzia narażał się na notę cenzorską lub pretorską multa $^{19}$. Jednak, z uwagi na to, że w procesie dwufazowym sę-

${ }^{14}$ J. Zabłocki, Iudex..., s. 220.

${ }^{15}$ Ibidem, s. 220-223.

${ }^{16}$ Gellius, Noctes Atticae 14,2,26: Verba ex oratione M. Catonis, cuius commeminit Favorinus, haec sunt: „Atque ego a maioribus memoria sic accepi: si quis quid alter ab altero peterent, si ambo pares essent, sive boni sive mali essent, quod duo res gessissent, uti testes non interessent, illi, unde petitur, ei potius credendum esse. Nunc si sponsionem fecisset Gellius cum Turio, ni vir melior esset Gellius quam Turius, nemo, opinor, tam insanus esset, qui iudicaret meliorem esse Gellium quam Turium: si non melior Gellius est Turio, potius oportet credi, unde petitu".

${ }^{17}$ Szerzej na temat argumentacji zob. J. Zabłocki, Iudex..., s. 224-225.

${ }^{18}$ Gellius, Noctes Atticae 14,2,25: Sed maius ego altiusque id esse existimavi, quam quod meae aetati et mediocritati conveniret, ut cognovisse et condemnasse de moribus, non de probationibus rei gestae viderer; ut absolverem tamen, inducere in animum non quivi et propterea iuravi mihi non liquere atque ita iudicatu illo solutus sum.

${ }^{19}$ M. Kaser, Das römische Zivilprozessrecht, München 1966, s. 284. Podobnie w przypadku arbiter ex compromisso, który powoływany był jako sędzia polubowny wyłącznie mocą decyzji stron, 
dzia wydawał wyrok w oparciu o własne przeświadczenie, istniała możliwość - z pewnością w procesie formułkowym, a może także w procesie legisakcyjnym - złożenia przysięgi stwierdzającej niemożność rozstrzygnięcia, co uwalniało sądzącego od wskazanej poważnej odpowiedzialności ${ }^{20}$. Oznacza to zatem, że sędzia, który nie mógł wydać wyroku zgodnego z przedstawionymi dowodami, a równocześnie z własnym sumieniem, miał możliwość uchylenia się od jego wydania. I z tej możliwości Gellius skorzystał ${ }^{21}$.

Paulus, D. 42,1,36: Pomponius libro trigensimo septimo ad edictum scribit, si uni ex pluribus iudicibus de liberali causa cognoscenti de re non liqueat, ceteri autem consentiant, si is iuraverit sibi non liquere, eo quiescente ceteros, qui consentiant, sententiam proferre, quia, etsi dissentiret, plurium sententia optineret.

W tym miejscu warto wskazać, że także w przypadku sądów kolegialnych sędzia miał możliwość powstrzymania się od wydania orzeczenia, przy czym nie wykluczało to wydania orzeczenia przez sąd kolegialny jako całość. Wedle twierdzenia Pomponiusa, przytoczonego przez Paulusa, w składzie kolegialnym możliwe jest, by jeden z orzekających złożył oświadczenie, że sprawa nie jest dla niego jasna. Wówczas, jeżeli większość sędziów była w stanie uzgodnić treść wyroku, możliwe było jego wydanie.

Celsus, D. 42,1,39: Duo ex tribus iudicibus uno absente iudicare non possunt, quippe omnes iudicare iussi sunt. sed si adsit et contra sentiat, statur duorum sententiae: quid enim minus verum est omnes iudicasse?

Do tożsamych wniosków prowadzi stwierdzenie Celsusa, który, odnosząc się do sądu trzyosobowego, wyraźnie wskazuje, że wydanie orzeczenia nie jest możliwe pod nieobecność jednego z sędziów, ale do wydania sentencji wystarczy zgoda dwóch z sędziów jako większości.

pretor dysponował tylko możliwością przymuszenia go do wydania wyroku za pomocą sankcji administracyjnych (multa, pignoris capio), jeśli po przyjęciu obowiązków nie wykonał ich terminowo, a nie miał przesłanek do excusatio. Zob. M. Żołnierczuk, Rzymskie sqdownictwo polubowne (okres przedklasyczny i klasyczny), Lublin 1978, s. 162, 165; R. Wojciechowski, Arbiter w prawie rzymskim, w: Postępowanie polubowne w dziejach. Materiały IX Konferencji historyków państwa i prawa, Wrocław 2006, s. 21-22.

${ }^{20}$ M. Kaser, op. cit., s. 88; W. Litewski, Rzymski proces cywilny, Kraków 1988, s. 61-62; J. Zabłocki, Iudex..., s. 225; J. G. Wolf, Iudex iuraratus, Rivista di Diritto Romano 4(2004), s. 15-16. Szerzej na ten temat zob. np. F. Leonhard, E. Weiss, s.v. Liquet, RE 13, col. 726-727.

${ }^{21} \mathrm{Na}$ gruncie obowiązku wydania orzeczenia przez arbitra, który na mocy umowy podjął się rozstrzygnięcia sporu, jeżeli wskazywał on na brak możliwości wydania wyroku z uwagi na niejasność sprawy, uznawano za zasadne wyznaczenie mu dłuższego czasu na zastanowienie (Ulpianus, D. $4,8,13,4)$. Szerzej na temat pozycji arbitra zob. np. M. Żołnierczuk, op. cit.; R. Wojciechowski, op. cit., s. 17-25 wraz z powołaną literaturą. 
Wypracowana w procesie dwufazowym instytucja przysięgi sibi non liquere w okresie późniejszym zanikła ${ }^{22}$. Początkowo w cognitio extra ordinem w przypadku wątpliwości co do prawa, a zapewne także w razie wątpliwości faktycznych, sędzia mógł przekazać sprawę do wyższej instancji (relatio) lub zwrócić się o ich rozstrzygnięcie do cesarza (consultatio ante sententiam) ${ }^{23}$. Na skutek powyższego sędzia otrzymywał sprawę do rozstrzygnięcia wraz ze wskazówkami lub sprawa była przejmowana do rozstrzygnięcia przez sąd wyższej instancji ${ }^{24}$. Jednakże w Noweli 125 z 543 roku Justynian ograniczył możliwość zwracania się do wyższej instancji o rozstrzygnięcie wątpliwości ${ }^{25}$, wprowadzając podwaliny pod współczesny obowiązek wydania wyroku.

III. Obowiązek wydania wyroku w prawie polskim. Myliłby się ten, kto by sądził, że problemy z wydaniem orzeczenia zniknęły wraz z przeminięciem antyku. Na dowód powyższego warto przytoczyć regulację art. 4 Kodeksu Napoleona, w którym przewidziano, że „sędzia wymawiaiący się od sądzenia, pod pozorem, że prawo milczy, ciemne jest, albo niedostateczne; może bydź pociaganym, iako winny odmówienia sprawiedliwości"26. Oczywiście nie można pominąć, że początkowo artykuł ten rozumiany był przede wszystkim jako domniemanie braku luk w Kodeksie, wyrażające przekonanie redaktorów, że stworzyli dzieło kompletne i niewymagające wykładni ${ }^{27}$, ale niewątpliwie oddaje on w pełni dostrzegane przez ustawodawcę niebezpieczeństwo powstrzymywania się przez sędziego od wydania wyroku ${ }^{28}$.

We współczesnym prawie polskim, podobnie jak w większości systemów prawnych, sędzia nie może uchylić się od wykonania swojego podstawowego

${ }^{22}$ A.M. Rabello, op. cit., s. 19.

${ }^{23}$ Temu zagadnieniu poświęcone są tytuły De relationibus: 29 księgi 11 Kodeksu Teodozjańskiego i 61 księgi 7 Kodeksu Justyniańskiego. Zob. też W. Litewski, op. cit., s. 93.

${ }^{24}$ A.M. Rabello, op. cit., s. 21.

${ }^{25}$ Novella 125,1: Iubemus igitur nullum iudicantium quolibet modo vel tempore pro causis apud se propositis nuntiare ad nostram tranquillitatem, sed examinare perfecte causam et quod eis iustum legitimumque videtur decernere; et si quidem partes cessaverint in his quae decreta sunt, executioni contradi sententiam secundum legum virtutem. Si autem aliquis putaverit ex prolata novissima sententia se laesum, appellatione utatur legitima, et haec secundum ordinem legibus definitum examinetur et perfectum suscipiat terminum. Si autem duo vel amplius fuerint cognitores litis, et aliqua inter eos emergat dissonantia, etiam sic iubemus unumquemque horum secundum quod videtur ei suam dare sententiam.

${ }^{26}$ Tekst Kodeksu Napoleona na podstawie Systemu Informacji Prawnej Lex, oparty na wydaniu Drukarni Księży Piiarów Warszawskich z 1808 r., które było urzędowym tekstem Kodeksu Napoleona w języku polskim.

${ }^{27}$ K. Sójka-Zielińska, Kodeks Napoleona. Historia i współczesność, wyd. 2, Warszawa 2008, s. 85; W. Wołodkiewicz, Mon Code est perdu! (na marginesie ksiażki Katarzyny Sójki-Zielińskiej o Kodeksie Napoleona), w: idem, Europa i prawo rzymskie. Szkice z historii europejskiej kultury prawnej, Warszawa 2009, s. 267.

${ }^{28}$ T. Giaro, w: W. Dajczak, T. Giaro, F. Longchamps de Bérier, Prawo rzymskie. U podstaw prawa prywatnego, Warszawa 2009, s. 38 - określił tę normę jako przestępstwo „odmowy wyrokowania”. 
obowiązku, jakim jest wydanie wyroku w sprawie: może jedynie uwzględnić lub oddalić żądanie powoda. Tylko w niektórych państwach w procedurze karnej może dojść do stwierdzenia, że dowody nie są wystarczające do wydania orzeczenia skazującego ${ }^{29}$.

Pobieżna nawet analiza polskiego kodeksu postępowania cywilnego ${ }^{30} \mathrm{uka}^{-}$ zuje, że nie przewidziano w nim miejsca na odmowę wydania wyroku przez sędziego/sędziów. Zgodnie z normą art. $324 \S 1$ zd. 1 k.p.c. sąd wydaje wyrok po niejawnej naradzie sędziów ${ }^{31}$. W komentarzach i metodykach pracy sędziego nie zawarto rozważań odnoszących się do sytuacji zbliżonej do opisywanej przez Aulusa Gelliusa ${ }^{32}$, także prace odnoszące się do wyrokowania w procesie cywilnym zagadnienie to pomijają ${ }^{33}$. Sędzia nie może zatem uchylić się od wykonania swojej funkcji z powołaniem na to, że okoliczności sprawy nie są dla niego jasne (wątpliwości co do stanu faktycznego), że brak możliwości jednoznacznego wyboru normy prawnej odpowiedniej do zastosowania w danym przypadku (wątpliwości co do stanu prawnego) lub nawet że brak w danej sytuacji normy prawnej (luka w prawie). Należy przy tym wskazać, że we współczesnym procesie cywilnym obowiązuje zasada, że non liquet co do faktów nie zwalnia sądu od wydania orzeczenia co do istoty sprawy. Przeciwnie, oczywiste jest w świetle art. 6 k.c. i art. 232 k.p.c., że musi wówczas zapaść orzeczenie niekorzystne dla strony dochodzącej swoich praw przed sądem ${ }^{34}$.

Podobnie na gruncie procedury karnej nie tylko brak przepisu dozwalającego na uchylenie się od wydania wyroku w sprawie budzącej wątpliwości, lecz dodatkowo w orzecznictwie podkreśla się, że sąd nie może uchylać się od podejmowania decyzji rozstrzygających o przedmiocie procesu - niezależnie od stopnia zawiłości sprawy, powinnością sądu jest przeprowadzenie dowodów wnioskowanych przez strony i ich ocena, w razie potrzeby przy wykorzystaniu (w zakresie wymagającym wiedzy specjalnej) opinii biegłych, zaś stopień skomplikowania dowodowego sprawy, złożoność okoliczności faktycznych, trudności w zakresie analizy, zrozumienia i oceny metod i sposobów przestępczego działania, nie uprawniają do przerzucenia powinności ich wyjaś-

${ }^{29}$ A.M. Rabello, op. cit., s. 1.

${ }^{30}$ Ustawa z dnia 17 listopada 1964 r. Kodeks postępowania cywilnego (Dz. U. Nr 43, poz. 296 ze zm.).

${ }^{31}$ Podobnie na gruncie postępowania karnego brak przepisu dozwalającego na uchylenie się od wydania wyroku (art. 408-419 ustawy z dnia 6 czerwca 1997 r. Kodeks postępowania karnego; Dz. U. Nr 89, poz. 555 ze zm., wskazują jednoznacznie, że po zamknięciu przewodu sądowego sąd przystępuje do narady, głosowania nad wyrokiem, sporządzenia go w formie pisemnej i ogłoszenia).

${ }^{32}$ Zob. np. B. Bladowski, Metodyka pracy sędziego cywilisty, wyd. 3, Warszawa 2009.

${ }^{33}$ Zob. np. W. Siedlecki, Zasady wyrokowania w procesie cywilnym, Warszawa 1957.

${ }^{34}$ L. Morawski, Domniemania a dowody prawnicze, Toruń 1981, s. 94; H. Mądrzak, Prawo do sqdu jako gwarancja ochrony praw czlowieka (studium na tle polskiego prawa konstytucyjnego, prawa cywilnego materialnego i procesowego), w: Podstawowe prawa jednostki i ich sadowa ochrona, red. L. Wiśniewski, Warszawa 1997, s. 190-191 - wraz z powołanymi w tych pracach wcześniejszymi publikacjami. 
nienia i rozstrzygnięcia rodzących się wątpliwości, na inne podmioty, w tym prokuratora ${ }^{35}$.

Sędziowski obowiązek wydania wyroku współcześnie wpisuje się w urzeczywistnienie zasady dostępu (obywateli) do sądu ${ }^{36}$. Prawo do sądu gwarantuje Konstytucja Rzeczypospolitej Polskiej ${ }^{37}$ i Konwencja o ochronie praw człowieka i podstawowych wolności ${ }^{38}$. Powszechnie przyjmuje się, że prawo do sądu obejmuje:

1. prawo dostępu do sądu (do uruchomienia procedury przed niezależnym, niezawisłym i bezstronnym sądem),

2. prawo do ukształtowania procedury przed sądem zgodnie z zasadami sprawiedliwości i jawności (prawo do rzetelnego procesu),

3. prawo do wyroku sądowego (wiążącego rozstrzygnięcia sprawy przez sąd) ${ }^{39}$.

Co istotne, prawo do sądu przysługuje jednostce (każdemu) wobec państwa niezależnie od istnienia i treści stosunku materialnoprawnego i wynikających z niego uprawnień i obowiązków ${ }^{40}$.

${ }^{35}$ Postanowienie Sądu Apelacyjnego we Wrocławiu z dnia 9 grudnia 2004 r., II AKz 491/04, Lex nr 154013.

${ }^{36}$ H. Pietrzkowski, Prawo do sqdu (wybrane zagadnienia), „Przegląd Sądowy” 9(1999), nr 11-12, s. 3; E. Gapska, Wady orzeczeń sqdowych, Warszawa 2009, s. 16-17.

${ }^{37}$ Każdy ma prawo do sprawiedliwego i jawnego rozpatrzenia sprawy bez nieuzasadnionej zwłoki przez właściwy, niezależny, bezstronny i niezawisły sąd (art. 45 ust. 1 Konstytucji Rzeczypospolitej Polskiej z dnia 2 kwietnia 1997 r., Dz.U. Nr 78, poz. 483 ze zm.).

${ }^{38}$ Każdy ma prawo do sprawiedliwego i publicznego rozpatrzenia jego sprawy w rozsądnym terminie przez niezawisły i bezstronny sąd ustanowiony ustawą przy rozstrzyganiu o jego prawach i obowiązkach o charakterze cywilnym albo o zasadności każdego oskarżenia w wytoczonej przeciwko niemu sprawie karnej (art. 6 ust. 1 zd. 1 Konwencji o ochronie praw człowieka i podstawowych wolności, sporządzonej w Rzymie dnia 4 listopada 1950 r., zmienionej następnie Protokołami nr 3, 5 i 8 oraz uzupełnionej Protokołem nr 2, Dz. U. z 1993 r. Nr 61 poz. 284 ze zm.).

${ }^{39}$ Wyrok Trybunału Konstytucyjnego z dnia 10 czerwca 2003 r., SK 37/02, OTK-A 2003/6/53. Zob. też Z. Czeszejko-Sochacki, Prawo do sqdu w świetle Konstytucji Rzeczypospolitej Polskiej (ogólna charakterystyka), „Państwo i Prawo” 1997, z. 11-12, s. 86-105; P. Pogonowski, Realizacja prawa do sqdu w postepowaniu cywilnym, Warszawa 2005, s. 7-16; H. Pietrzkowski, Prawo do rzetelnego procesu w świetle zmienionej procedury cywilnej, „Przegląd Sądowy” 15(2005), nr 10, s. 37; M. Romańska, Skarga na przewlektość postępowania sqqdowego, „Przegląd Sądowy” 15(2005), nr 11-12, s. 41; A. Kubiak, Konstytucyjna zasada prawa do sqdu w świetle orzecznictwa Trybunatu Konstytucyjnego, Łódź 2006, s. 68, 185-232; Postępowanie cywilne, red. E. Marszałkowska-Krześ, wyd. 2, Warszawa 2011, s. 57.

Szerzej na temat prawa do sądu, a w szczególności jego znaczenia dla postępowania cywilnego, zob. L. Garlicki, Prawo do sadu, w: Prawa człowieka. Model prawny, Warszawa 1991, s. 537-560; H. Mądrzak, op. cit., s. 186-200; K. Korzan, Roszczenie procesowe jako przedmiot postępowania cywilnego w kontekście prawa dostępu do sqadu i prawa do powództwa, w: Symbolae Vitoldo Broniewicz dedicatae. Księga pamiatkowa ku czci Witolda Broniewicza, Łódź 1998, s. 175-193; H. Pietrzkowski, Prawo do sqdu..., s. 3-17; A. Krzywonos, J. Gołaczyński, Prawo do sqdu, w: Prawa i wolności obywatelskie w Konstytucji RP, red. B. Banaszak, A. Preisner, Warszawa 2002, s. 725-743; E. Łętowska, O definicji prawa do sqdu, „Państwo i Prawo” 57(2002), z. 12, s. 78; H. Pietrzkowski, Prawo do rzetelnego..., s. 37-54; P. Pogonowski, op. cit. - wraz z dalszymi pracami w nich powołanymi.

${ }^{40}$ K. Korzan, op. cit., s. 186, 188; H. Pietrzkowski, Prawo do sqdu..., s. 6. 
Funkcja i istota wymiaru sprawiedliwości wyraża się przede wszystkim w wydawaniu aktów władczych, jakimi są orzeczenia sądowe - sąd ma bowiem sprawę rozpatrzyć, a nie tylko rozpatrywać ${ }^{41}$. Nic zatem dziwnego, że prawo do wyroku jest uwieńczeniem prawa do sądu ${ }^{42}$. Podkreślenia wymaga, że zadaniem „sądu” jest przeprowadzić właściwą analizę twierdzeń, argumentów oraz dowodów powoływanych przez strony, bez uprzedzeń w swoim osądzie, czy mają one związek z jego decyzjami, nie zaś wydać orzeczenie treści odpowiadającej oczekiwaniom jednej ze stron ${ }^{43}$.

$\mathrm{Na}$ obowiązek wydania przez sędziego orzeczenia wskazuje się także w zbiorze zasad etyki sędziowskiej, zakazując nadużywania instytucji wyłączenia sędziego. Sędzia może bowiem złożyć wniosek o wyłączenie od rozpoznania sprawy tylko wtedy, gdy istnieją do tego uzasadnione podstawy (§ 15 zbioru zasad etyki sędziowskiej ${ }^{44}$ ).

$\mathrm{Z}$ uwagi na to, że odwlekanie wymierzenia sprawiedliwości jest jej zaprzeczeniem ${ }^{45}$ jednym ze środków mających dyscyplinować sędziów do wydawania orzeczeń w rozsądnym terminie, a zatem bez nieuzasadnionej zwłoki, jest instytucja skargi na przewlekłość postępowania ${ }^{46}$ oraz powiązana $\mathrm{z}$ nią regulacja art. $417^{1} \S 3$ k.c. określająca obowiązek naprawienia szkody wynikającej m.in. $\mathrm{z}$ niewydania orzeczenia $\mathrm{w}$ rozsądnym terminie ${ }^{47}$. Zgodnie $\mathrm{z}$ treścią art. 2 ust. 1 ustawy z dnia 17 czerwca 2004 roku o skardze na naruszenie prawa strony do rozpoznania sprawy w postępowaniu przygotowawczym prowadzonym

${ }^{41}$ E. Gapska, op. cit., s. 17.

${ }^{42}$ P. Pogonowski, op. cit., s. 11.

${ }^{43}$ Wyrok Europejskiego Trybunału Praw Człowieka z dnia 19 kwietnia 1994 r., 16034/90, LEX nr 80534. Zob. też H. Mądrzak, op. cit., s. 197.

${ }^{44}$ Załącznik do uchwały Nr 16/2003 Krajowej Rady Sądownictwa z dnia 19 lutego 2003 r. w sprawie uchwalenia zbioru zasad etyki zawodowej sędziów stanowiącego załącznik do uchwały (http://www.krs.pl/main2.php?node=ethics, data wejścia 2011.10.23).

${ }^{45} \mathrm{~K}$. Piasecki, Aby strony swarów prawnych rychty koniec mieli, „Gazeta Prawnicza” z dnia 16 grudnia 1977 roku.

${ }^{46}$ Celem skargi na przewlekłość jest zlikwidowanie opieszałości sądu, przed którym sprawa zawisła, poprzez wymuszenie należytej sprawności sądu i nadanie sprawie odpowiedniego biegu. Skarga na przewlekłość ma zapewnić szybką reakcję na trwającą zwłokę w czynnościach sądu. Wniesienie skargi na przewlekłość postępowania ma bowiem służyć dyscyplinowaniu czynności podejmowanych na danym etapie toczącego się jeszcze postępowania w określonej sprawie. Szerzej zob. np. postanowienie Sądu Najwyższego z dnia 8 lipca 2005 r., III SPP 120/05, OSNP 2006/5-6/102; postanowienie Sądu Najwyższego z dnia 6 lutego 2006 r., III SPP 163/05, OSNP 2007/5-6/87; postanowienie Sądu Najwyższego z dnia 21 września 2010 r., III SPP 19/10, LEX nr 667498; K. Piasecki, Przewlekłość postępowania w sprawach cywilnych - przyczyny i środki zaradcze, „Nowe Prawo” 45(1989), nr 4, s. 29-39; J. Przybylska, Odpowiedzialność państwa za przewlekłość postęowania w sprawach cywilnych, ,Rejent” 14(2004), nr 9, s. 65-87; M. Romańska, op. cit., s. 39-73; K. Gonera, Przewlekłość postępowania w sprawach cywilnych, „Przegląd Sądowy” 15(2005), nr 11-12, s. 3-38; P. Górecki, S. Stachowiak, P. Wiliński, Skarga na przewlekłość postępowania przygotowawczego i sqdowego. Komentarz, wyd. 2, Warszawa 2010.

${ }^{47} \mathrm{Na}$ ten temat zob. np. Z. Banaszczyk, Odpowiedzialność za szkode wyrzqdzonq niewydaniem orzeczenia sqdowego we właściwym czasie (art. $417^{1}$ \& 3 k.c.), „Palestra” 2006, nr 9-10, s. 9-18. 
lub nadzorowanym przez prokuratora i postępowaniu sądowym bez nieuzasadnionej zwłoki ${ }^{48}$ przewlekłość postępowania ma miejsce, jeżeli postępowanie w tej sprawie trwa dłużej, niż to konieczne dla wyjaśnienia tych okoliczności faktycznych i prawnych, które są istotne dla rozstrzygnięcia sprawy, albo dłużej niż to konieczne do załatwienia sprawy egzekucyjnej lub innej dotyczącej wykonania orzeczenia sądowego. Niewątpliwie przywołana ustawowa definicja odwołuje się do trwania postępowania, a zatem do sytuacji, w której nie doszło jeszcze do wydania orzeczenia. Co istotne, ustawodawca w żaden sposób nie odnosi się do ewentualnych wątpliwości, przed którymi staje sędzia, nakładając nań obowiązek wyrokowania w rozsądnym terminie niezależnie od targających nim wątpliwości.

IV. Na koniec warto przytoczyć dwie anegdoty ukazujące sposoby uniknięcia przez sędziego wydania wyroku w sprawie wątpliwej. Pokazują one, że trudności w wymierzaniu sprawiedliwości zgodnej nie tylko z literą prawa, ale także ze słusznością, są ponadczasowe i ponadnarodowe. I tak, w Smyrnie w I wieku p.n.e. postawiono ponoć przed sąd kobietę, która otruła męża i syna z drugiego małżeństwa. Prokonsul Azji Dolabella nie potrafił wydać orzeczenia, ponieważ kobieta tłumaczyła swoje postępowanie tym, że zabici uprzednio haniebnie pozbawili życia jej syna z pierwszego małżeństwa. Ostatecznie sprawa stanęła do osądzenia przed ateńskim Areopagiem, który po pierwszej rozprawie, odroczył rozpoznanie sprawy o 100 lat, praktycznie uchylając się od wydania wyroku skazującego ${ }^{49}$.

O podobnych dylematach świadczyła historia Chilona ze Sparty, który rozpoznawał w składzie trzyosobowym sprawę swego przyjaciela, zagrożoną karą śmierci. Jako że przepisy prawa nakazywały w tym przypadku wydanie wyroku skazującego, mędrzec oddał swój głos za skazaniem, uprzednio przekonawszy pozostałych sędziów do głosowania za uniewinnieniem. W ten sposób nie złamał prawa, ale także nie wystapił przeciwko przyjacielowi ${ }^{50}$.

Analiza regulacji prawa rzymskiego, zwłaszcza okresu klasycznego, świadczy o słusznym przekonaniu, że nie w każdej sytuacji sędzia jest w stanie wydać orzeczenie zgodne zarówno z przedstawionymi dowodami, jak i własnym sumieniem. Możliwość uchylenia się od wydania wyroku z powodu niejasności sprawy jawi się jako głęboko humanitarna regulacja otwarta na uwzględnienie zasad sprawiedliwości i słuszności.

Niestety profesjonalizacja zawodu sędziego doprowadziła ustawodawców do odmówienia orzecznikom możliwości uchylenia się od wydania wyroku. Sędzia zobowiązany jest do wydania orzeczenia, a częstokroć także jego uza-

\footnotetext{
${ }^{48}$ Dz. U. Nr 179, poz. 1843 ze zm.

${ }^{49}$ Gellius, Noctes Atticae 12,7,1-7; Valerius Maximus 8,1, amb.2.

${ }^{50}$ Gellius, Noctes Atticae 1,3,2-9. Szerzej zob. J. Zabłocki, Rozważania ..., s. 104-106.
} 
sadnienia, choćby sprawa pozostawała dla niego niejasna. Wynika to zarówno z obowiązku posiadania przez sędziów wykształcenia prawniczego, jak i ukształtowania czynności sędziowskich nie jako wykonywania obywatelskiego obowiązku, a jedynie formy zarobkowania (choć określanej mianem służby). Usunięciu ewentualnych błędów powstałych na skutek możliwej przypadkowości wydanego orzeczenia służyć ma rozwinięty system apelacyjny.

\section{JUDICIAL DUTY TO DELIVER A JUDICIAL DECISION. ROMAN LAW REGULATIONS AND THE POLISH LAW}

\section{$\mathrm{S} \mathrm{u} \mathrm{m} \mathrm{m} \mathrm{a} \mathrm{r} \mathrm{y}$}

In the Roman legislative process, the task of dissolving a dispute was vested in a private individual of a high social rank, but who usually lacked legal knowledge and experience. And yet, the law required from such judges due performance of their duties, and even provided for death penalty for a judge who had decided in favour of the party who paid him. Already in the $2^{\text {nd }}$ century BC a judge's liability was recognised for litem suam facere or improper conduct such as, inter alia, failure to deliver a decision, failure to keep the dates of trails, absence during a trail, or incompatibility of the judgment with the formula provided for in condemnatio. Therefore, in recognition of the potential difficulties of making a wrong decision as a consequence of a lack of legal knowledge or other necessary capabilities, judges were granted a right to turn to jurists or philosophers for advice, or could even take an oath in which they claimed their inability to solve the matter (sibi non liquere).

In the contemporary Polish legal system, similarly to most other legal systems, judges may not refrain or escape from fulfilling their fundamental duty such as delivering a judgment, and justify such failure by unclear circumstances (doubts as to the actual circumstances), the absence of an unambiguous legal norm to apply in a given case (doubts as to the legal state of affairs) or an absence of an applicable norm (a gap in legal regulations). Today, the judicial duty to deliver a judgment arises from the requirement to implement and realise the principle of public access to the courts of justice, provided for, in Poland, in article $417 \S 3$ of the Civil Code. 


\title{
L'OBLIGATION DU JUGE DE PRONONCER UN JUGEMENT. RÉGULATIONS DU DROIT ROMAIN ET LE DROIT POLONAIS
}

\author{
$\mathrm{R}$ é s u m é
}

Dans la procédure romaine legis actiones et de formules, la tâche de trancher sur un litige est confiée à un particulier de haut niveau social, mais souvent dépourvue de connaissance et d'expertise juridique. Malgré cela, le droit porte une attention particulière à la bonne exécution des obligations du juge. La loi des XII Tables prévoit la peine de mort pour un juge qui fait sien un litige (litem suam facere), suite à une attitude inappropriée: la non prononciation de jugement, le non respect de la date d'audience, l'absence pendant l'audience, la non conformité du jugement à la formule de procès indiquée dans la condemnatio etc... C'est sans doute pour cela, en cas de difficultés que le juge tout seul ne saura pas affronter, faute des connaissances juridiques et des compétences juridictionnelles, qu'il est prévu un droit au conseil des juristes ou celui des philosophes et même une possibilité de prêter serment visant à constater l'incapacité de trancher sur l'affaire (sibi non liquere).

Au niveau de la procédure de cognition, est déjà exclue la possibilité de se soustraire à la prononciation du jugement et de rendre Siudo à l'instance supérieure afin qu'elle juge sur les doutes juridiques, tout cela constituant des bases pour l'obligation contemporaine de rendre un jugement.

Dans le droit polonais contemporain, comme d'ailleurs dans la plupart des systèmes juridiques, le juge ne peut pas se soustraire à l'exécution de son obligation principale, c'est-à-dire à la prononciation d'un jugement dans l'affaire, expliquant que les circonstances ne sont pas claires pour lui (doutes quant à l'état des faits), qu'il est dans l'impossibilité de faire un choix précis de la bonne norme juridique applicable (doute quant à l'état juridique) ou même l'impossibilité de choisir sans ambiguité la bonne norme juridique (lacune du droit). L'obligation des juges de rendre un jugement s'inscrit de nos jours dans la réalisation du principe portant sur l'accessibilité des citoyens à la juridiction, cette réalisation devant être garantie par l'institution dite plainte contre l'atermoiement de la procédure et par une régulation attachée, prévue à l'art. $417^{1} \mathrm{du}$ $\S 3$ du code civil, déterminant l'obligation de réparer le préjudice subi suite à la non prononciation du jugement dans un délai raisonnable. 